University of Nebraska - Lincoln

DigitalCommons@University of Nebraska - Lincoln

\title{
INTRAMUSCULAR COLLAGEN AND SERUM HYDROXYPROLINE AS RELATED TO IMPLANTED TESTOSTERONE, DIHYDROTESTOSTERONE AND ESTRADIOL-17 $\beta$ IN GROWING WETHERS
}

L. F. Miller

International Minerals \& Chemicals INC.

M. D. Judge

Purdue University

B. D. Schanbacher

USDA-ARS

Follow this and additional works at: https://digitalcommons.unl.edu/usdaarsfacpub

Part of the Agricultural Science Commons

Miller, L. F.; Judge, M. D.; and Schanbacher, B. D., "INTRAMUSCULAR COLLAGEN AND SERUM

HYDROXYPROLINE AS RELATED TO IMPLANTED TESTOSTERONE, DIHYDROTESTOSTERONE AND ESTRADIOL-17 $\beta$ IN GROWING WETHERS" (1990). Publications from USDA-ARS / UNL Faculty. 777. https://digitalcommons.unl.edu/usdaarsfacpub/777

This Article is brought to you for free and open access by the U.S. Department of Agriculture: Agricultural Research Service, Lincoln, Nebraska at DigitalCommons@University of Nebraska - Lincoln. It has been accepted for inclusion in Publications from USDA-ARS / UNL Faculty by an authorized administrator of DigitalCommons@University of Nebraska - Lincoln. 


\title{
INTRAMUSCULAR COLLAGEN AND SERUM HYDROXYPROLINE AS RELATED TO IMPLANTED TESTOSTERONE, DIHYDROTESTOSTERONE AND ESTRADIOL-17 $\beta$ IN GROWING WETHERS 1
}

\author{
L. F. Miller ${ }^{2}$, M. D. Judge ${ }^{3}$ and B. D. Schanbacher ${ }^{4}$ \\ Purdue University, W. Lafayette, IN 47907 and \\ U.S. Department of Agriculture, Clay Center, NE 68933
}

\begin{abstract}
Relationships of implanted testosterone, dihydrotestosterone and estradiol-17 $\beta$ to collagen degradation and intramuscular collagen concentration and stability were determined. Intramuscular collagen content, solubility and shrinkage temperature and serum hydroxyproline were analyzed in groups of six rams, wethers, and wethers implanted with various levels of testosterone or dihydrotestosterone (Exp. 1) and groups of $10 \mathrm{rams}$, wethers and wethers implanted with estradiol-173, dihydrotestosterone or a combination of these two steroids (Exp. 2). Intramuscular collagen content in both experiments was higher $(P<.05)$ in muscles of rams than in muscles of wethers. Administration of the highest level of testosterone to wethers raised $(P<.05)$ total and insoluble intramuscular collagen to concentrations noted in rams. Administration of the testosterone metabolite, dihydrotestosterone, to wethers had no effect on intramuscular collagen. Administration of estradiol-17 $\beta$ to wethers tended to raise concentrations of intramuscular collagen so that they were no longer lower $(P<.05)$ than those in rams. Collagen stability as measured by solubility and thermal shrinkage temperature did not differ among rams, wethers or implanted wethers $(P>.05)$. Increases in collagen accretion due to hormone administration were observed to be the result of increases in the insoluble portion of the intramuscular collagen $(P<.05)$.
\end{abstract}

(Key Words: Lambs, Androgen, Estrogen, Collagen, Hydroxyproline.)

J. Anim. Sci. 1990. 68:1044-1048

\section{Introduction}

Tenderness problems in intact males have been associated with connective tissue (Boccard et al., 1979; Judge et al., 1984; Crouse et al., 1985), but a clear association between testosterone and intramuscular collagen has not been demonstrated (Miller et al., 1989). Testosterone levels in the serum of bulls closely parallel serum levels of nonprotein hydroxy-

\footnotetext{
${ }^{1}$ Journal Paper No. 11,244 of the Purdue Agric. Exp. Sta. Dept. of Anim. Sci.

2Present address: International Minerals \& Chemicals INC., Box 207, Terre Haute, IN 47808.

${ }^{3}$ Dept of Anim. Sci., Purdue Univ.

${ }^{4}$ Roman L. Hruska U.S. Meat Anim. Res. Center, ARS.

Received January 11, 1989.

Accepted August 11, 1989.
}

proline (Gerrard et al., 1987). Because release of testosterone from the gonad is pulsatile, any single-point measurement of its concentration in blood may not reflect accurately the extent of its influence on intramuscular collagen. Implantation of testosterone or its metabolites provides a more uniform level of hormone to which tissues are exposed.

The following experiments were conducted to assess the influence of constant levels of testosterone (T), estradiol-17 $\beta\left(\mathbf{E}_{2}\right)$ and dihydrotestosterone (DHT) on whole-body collagen degradation and intramuscular collagen concentration and maturation.

\section{Experimental Methods}

Experiment 1 . Forty-eight ram lambs were assigned randomly and equally $(n=6)$ to treatments of rams, wethers, T-implanted 
wethers or DHT-implanted wethers. Rams to be used as wethers were castrated surgically at birth. Implanted wethers received one, three or six Silastic capsules $(30 \mathrm{~cm}$ in length) of $T$ or DHT at approximately $30 \mathrm{~kg}$ body weight. The construction and placement of these implants have been described previously (Schanbacher, 1980a,b; D'Occhio et al., 1982). Blood samples were taken via venipuncture at implantation and at 14-d intervals to $56 \mathrm{~d}$ postimplantation, at which time the animals were slaughtered. Serum was extracted with five volumes of cold $\left(4^{\circ} \mathrm{C}\right) 95 \%$ ethanol and centrifuged at $1,000 \times g$. Supernatant fluid was evaporated under vacuum and residues were redissolved in volumes of water equal to that of the original serum. Reconstituted samples then were analyzed for hydroxyproline as reported by Bergman and Loxley (1963).

Samples of the longissimus muscle (12th rib) were excised, stripped of fat and epimysium and frozen in liquid nitrogen within $1 \mathrm{~h}$ postexsanguination. Muscles were subdivided with representative subsamples allocated to separate analyses for total collagen, collagen solubility and collagen thermal shrinkage. Total intramuscular collagen and collagen solubility were determined according to Hill (1966) using the hydroxyproline procedure of Bergman and Loxley (1963). Collagen content was calculated from hydroxyproline concentration by multiplying by 7.25 . Physical isolation of the intramuscular collagen was accomplished by frozen differential fragmentation as reported by McClain (1969). Differential scanning calorimetry ${ }^{5}$ was conducted on the isolated material to determine the onset temperature of the thermal shrinkage reaction as reported by McClain and Wiley (1972).

Experiment 2. Fifty ram lambs were assigned randomly and equally to treatments $(n=$ 10) of rams, wethers, wethers implanted with one silastic capsule $\left(30 \mathrm{~cm}\right.$ long) of $E_{2}$, wethers implanted with three silastic capsules ( $30 \mathrm{~cm}$ long) of DHT and wethers implanted with one capsule of $E_{2}$ and three capsules of DHT. Rams to be used as wethers were castrated at birth. Blood and muscle samples were collected and analyzed as in Exp. 1

\footnotetext{
${ }^{5}$ Dupont 990 Thermal Analyzer equipped with a 910 Differential Scanning Calorimeter cell base, E. I. Dupont De Nemours \& Co., Wilmington, DE.
}

except that blood samples collected at implartation were pooled for hydroxyproline analyses because no interaction between sampling time and treatment existed in Exp. 1

Statistical Analyses. Serum hydroxyproline data from Exp. 1 were analyzed using a twoway analysis of variance as described by Harvey (1975) where in the factors were the eight treatment groups and the four sampling times. Serum hydroxyproline data from Exp. 2 and muscle data from both experiments were analyzed utilizing a one-way analysis of variance described by Anderson and McLean (1974) in which the eight treatment groups in Exp. 1 and the five treatment groups in Exp 2 were the factors. Duncan's Multiple Range Test was employed to separate means when significant effects were observed (Duncan, 1955).

\section{Results}

Experiment 1. In agreement with our previous report (Miller et al., 1989), total intramuscular collagen concentrations were greater $(P<.05)$ in rams than in wethers (Table 1). Implantation of $T$ in wethers increased $(P<.05)$ total collagen concentration, and the response tended to increase with the level of $T$ implanted, whereas implantation of DHT did not $(P>.05)$ alter total collagen concentration. Rams had greater $(P<.05)$ concentration of soluble collagen than wethers, with implantation of $\mathrm{T}$ at the highest dose increasing $(P<.05)$ soluble collagen concentration. Implantation of DHT did not change $(P$ $>$.05) the content of soluble intramuscular collagen. The concentrations of insoluble collagen was greater $(P<.05)$ in muscles of rams than in muscles of wethers, and $\mathrm{T}$ implantation at the highest level increased $(P<.05)$ insoluble collagen concentration. Increasing the level of $T$ implantation tended to increase insoluble collagen concentration. Implanted DHT did not change $(P>.05)$ the concentration of insoluble intramuscular collagen. These data suggest that the higher content of total intramuscular collagen in rams was due to $T$ rather than to DHT, but the $\mathrm{T}$ did not change the proportions of soluble and insoluble collagen, as evidenced by uniform percentage of solubility in all groups (Table 1). However, because about $80 \%$ of total collagen is in the insoluble fraction, the $\mathrm{T}$ effect occurred mainly in the insoluble fraction. No differences $(P>$ $.05)$ in thermal shrinkage temperature were 
TABLE 1. INTRAMUSCULAR COLLEGEN IN RAMS, WETHERS AND IMPLANTED WETHERS (EXP. 1)

\begin{tabular}{|c|c|c|c|c|c|c|c|c|c|}
\hline \multirow[b]{3}{*}{ Variable } & \multirow[b]{3}{*}{ Rams } & \multirow[b]{3}{*}{ Wethers } & \multicolumn{6}{|c|}{ Wether implantation, no. of capsules } & \multirow[b]{3}{*}{ SE } \\
\hline & & & \multicolumn{3}{|c|}{ Testosterone } & \multicolumn{3}{|c|}{ Dihydrotestosterone } & \\
\hline & & & 1 & 3 & 6 & 1 & 3 & 6 & \\
\hline \multicolumn{10}{|l|}{ Intramuscular collagen } \\
\hline Total, $\mathrm{mg} / \mathrm{g}^{\mathrm{c}}$ & $4.33^{\mathrm{a}}$ & $3.27^{\mathrm{b}}$ & $3.75^{\mathrm{ab}}$ & $3.92^{\mathrm{ab}}$ & $4.29^{\mathrm{a}}$ & $3.46^{\mathrm{b}}$ & $3.69^{\mathrm{ab}}$ & $3.49^{\mathrm{b}}$ & .26 \\
\hline Soluble, $\mathrm{mg} / \mathrm{g}^{\mathrm{c}}$ & $.87^{\mathrm{a}}$ & $.64^{\mathrm{b}}$ & $.73^{\mathrm{ab}}$ & $.69^{a b}$ & $.89^{\mathrm{a}}$ & $.79^{\mathrm{ab}}$ & $.79^{\mathrm{ab}}$ & $.65^{b}$ & .06 \\
\hline Insoluble, $\mathrm{mg} / \mathrm{g}^{\mathrm{c}}$ & $3.46^{\mathrm{a}}$ & $2.63^{\mathrm{b}}$ & $3.03^{\mathrm{ab}}$ & $3.22^{\mathrm{ab}}$ & $3.40^{\mathrm{a}}$ & $2.67^{b}$ & $2.89^{\mathrm{ab}}$ & $2.84^{\mathrm{ab}}$ & .21 \\
\hline \multicolumn{10}{|l|}{ Thermal shrinkage } \\
\hline Solubility, \% & $20.20^{2}$ & $19.68^{\mathrm{a}}$ & $19.34^{\mathrm{a}}$ & $17.88^{\mathrm{a}}$ & $20.78^{\mathrm{a}}$ & $22.23^{\mathrm{a}}$ & $\begin{array}{l}00.2 \\
21.60^{\mathrm{a}}\end{array}$ & $18.65^{\mathrm{a}}$ & 1.17 \\
\hline
\end{tabular}

a,b Means in the same row without common superscripts differ $(P<.05)$.

'Wet weight basis.

noted. Circulating concentrations of steroids in these implanted wethers are presented elsewhere (Schanbacher et al., 1987).

Serum hydroxyproline concentrations decreased $(P<.05)$ at each interval postimplantation, corresponding to decreased collagen turnover in older animals (Table 2). These agerelated differences were similar to those observed in both rams and wethers in an earlier study (Miller et al., 1989). Rams and Timplanted wethers tended to have greater serum hydroxyproline than nonimplanted wethers in a dose-dependent trend (data not shown), but these differences were not significant $(P>.05)$.

Experiment 2. No differences $(P>.05)$ were found in serum hydroxyproline concentrations among these treatments, although rams and implanted wethers tended to have higher levels than nonimplanted wethers (Table 3). Total intramuscular collagen concentration was greater $(P<.05)$ in rams than in untreated wethers or in wethers treated only with DHT. In wethers implanted with $E_{2}$ alone or in combination with DHT, total intramuscular collagen tended to be intermediate between rams and untreated wethers. Soluble collagen tended to be higher in rams and $E_{2}$-implanted wethers (alone or in combination with DHT) than in nonimplanted wethers or in wethers implanted with DHT alone, but these differences were not significant $(P>.05)$. Insoluble collagen concentration was higher $(P<.05)$ in rams than in nonimplanted wethers or wethers implanted with DHT but was similar $(P>.05)$ in rams and $E_{2}$-implanted wethers. Thermal shrinkage temperature and percentage of solubility of collagen did not differ $(P>.05)$ among treatment groups.

\section{Discussion}

Intact rams have higher levels of intramuscular collagen than wethers do, probably as a result of circulating testosterone; DHT does not appear to be an intermediate in this effect. Higher concentration of total intramuscular collagen in rams than in wethers is in agreement with earlier work with lambs that showed that the differences were independent of intramuscular fat content (Miller et al., 1989). These findings also agree with those on other species (Boucek and Noble 1961; Boccard et al., 1979; Crouse et al., 1985; Gerrard et al., 1987).

The results indicate that growing rams do not differ consistently from wethers in muscle collagen stability as indicated by percentage of solubility or thermal shrinkage temperature. This finding and earlier work with lambs

TABLE 2. SERUM HYDROXYPROLINE AS INFLUENCED BY POSTIMPLANTATION SAMPLING TIME (EXP. 1)

\begin{tabular}{llllll}
\hline \hline & \multicolumn{4}{c}{ Sampling time, $\mathrm{d}$} & \\
\cline { 2 - 6 } Variable & 14 & 28 & 42 & 56 & SE \\
\hline Serum hydroxyproline, $\mu \mathrm{g} / \mathrm{ml}$ & $6.04^{\mathrm{a}}$ & $5.06^{\mathrm{b}}$ & $4.66^{\mathrm{c}}$ & $4.06^{\mathrm{d}}$ & .12 \\
\hline
\end{tabular}

a,b,c,d Means without common superscripts differ $(P<.05)$. 
TABLE 3. COLLAGEN PARAMETERS IN RAMS, WETHERS AND IMPLANTED WETHERS (EXP. 2)

\begin{tabular}{|c|c|c|c|c|c|c|}
\hline \multirow[b]{2}{*}{ Variable } & \multirow[b]{2}{*}{ Rams } & \multirow[b]{2}{*}{ Wethers } & \multicolumn{3}{|c|}{$\begin{array}{c}\text { Wether implantation, } \\
\text { no. of capsules }\end{array}$} & \multirow[b]{2}{*}{ SE } \\
\hline & & & $3 \mathrm{DHT}^{\mathrm{a}}$ & $1 \mathrm{E}_{2}^{\mathrm{b}}$ & $\begin{array}{l}3 \mathrm{DHT}^{\mathrm{a}} \\
+1 \mathrm{E}_{2}^{\mathrm{b}} \\
\end{array}$ & \\
\hline $\begin{array}{l}\text { Serum hydroxyproline, } \mu \mathrm{g} / \mathrm{ml} \\
\text { Intramuscular collagen }\end{array}$ & $4.82^{c}$ & $4.20^{c}$ & $4.63^{c}$ & $4.97^{c}$ & $5.07^{\mathrm{c}}$ & .26 \\
\hline Total, $\mathrm{mg} / \mathrm{g}^{\mathrm{e}}$ & $4.71^{\mathrm{c}}$ & $3.89^{\mathrm{d}}$ & $3.92^{\mathrm{d}}$ & $4.21^{\mathrm{cd}}$ & $4.13^{\mathrm{cd}}$ & .18 \\
\hline Soluble, $\mathrm{mg} / \mathrm{g}^{\mathrm{e}}$ & $.75^{\mathrm{c}}$ & $.56^{\mathrm{c}}$ & $.57^{c}$ & $.60^{c}$ & $.75^{\mathrm{c}}$ & .08 \\
\hline Insoluble, $\mathrm{mg} / \mathrm{g}^{e}$ & $3.96^{\mathrm{c}}$ & $3.32^{\mathrm{d}}$ & $3.35^{\mathrm{d}}$ & $3.61^{\mathrm{cd}}$ & $3.39^{\mathrm{d}}$ & .14 \\
\hline Thermal shrinkage temp., ${ }^{\circ} \mathrm{C}$ & $64.0^{\mathrm{c}}$ & $63.8^{\mathrm{c}}$ & $63.5^{\mathrm{c}}$ & $63.7^{\mathrm{c}}$ & $63.5^{\mathrm{c}}$ & .30 \\
\hline Solubility, $\%$ & $15.55^{\mathrm{C}}$ & $14.57^{\mathrm{c}}$ & $14.73^{c}$ & $14.22^{\mathrm{c}}$ & $17.40^{\mathrm{c}}$ & 1.44 \\
\hline
\end{tabular}

(Miller et al., 1989) showing greater collagen stability in wethers than in rams contrast with work in beef that indicated that an accelerated rate of collagen maturation occurs in bulls compared with steers (Boccard et al., 1979; Judge et al., 1984; Crouse et al., 1985; Gerrard et al., 1987). The range of physiological maturity in the present experiments may have been insufficient to detect an accelerated collagen maturation process or, alternatively, age-associated collagen maturation may occur more slowly in rams than in bulls.

Gonadal steroid replacement increased collagen metabolism in wethers. Implantation of $T$ produced collagen characteristics in wethers similar to those in their gonadally intact contemporaries. Implantation of DHT did not produce these effects, suggesting that $T$ does not affect collagen in muscle tissue through transformation to DHT as it does in reproductive tissues. Estrogenic implants are growth stimulants and estrogen receptors have been characterized recently in muscle (Meyer and Rapp, 1985). The tendency of implanted $E_{2}$ to increase intramuscular collagen suggests that $T$ may act through conversion to $E_{2}$ or together with $E_{2}$ to stimulate collagen synthesis. Also, estrogens increase growth hormone secretion in wethers, and growth hormone secretion is greater in rams than in wethers (Davis et al., 1977).

\section{Implications}

Stimulation of growth with either endogenous or exogenous anabolic steroids results in increased collagen accretion. A maturation effect of these hormones on the muscle collagen of lambs consisting of increased collagen crosslinking was not observed in this study.

\section{Literature Cited}

Anderson, V. L. and R. A. McLean. 1974. Design of Experiment: A Realistic Approach. Marcel Dekker, New York.

Bergman, I. and R. Loxley. 1963. Two improved and simplified methods for the spectrophotometric determination of hydroxyproline. Anal. Chem. 35:1961.

Boccard, R. L., R. T. Naude, D. E. Cronje, M. C. Smit, H. J. Venter and E. J. Rossouw. 1979. The influence of age, sex and breed of cattle on their muscle characteristics. Meat Sci. 3:261.

Boucek, R. J. and N. L. Noble. 1961. Metabolism of collagen. Biochem. J. 80:148.

Crouse, J. D., H. R. Cross and S. C. Seideman. 1985. Effects of sex condition, genotype, diet and carcass electrical stimulation on the collagen content and palatability of two bovine muscles. J. Anim. Sci. 60:1228.

Davis, S. L., D. L. Ohlson, J. Klindt and M. S. Anfinson. 1977. Episodic growth hormone secretory patterns in sheep: Relationships to gonadal steroid hormones. Am. J. Physiol. 23:E519.

D'Occhio, M. J., B. D. Schanbacher and J. E. Kinder. 1982. Relationship between serum testosterone concentration and patterns of luteinizing hormone secretion in male sheep. Endocrinology 110:1547.

Duncan, D. B. 1955. Multiple range and multiple F tests. Biometrics 1:4

Gerrard, D. E., S. J. Jones, E. D. Aberle, R. P. Lemenager, M. A. Diekman and M. D. Judge. 1987. Collagen stability, testosterone secretion and meat tendemess in growing bulls and steers, J. Anim. Sci. 65:1236.

Harvey, W. R. 1975. Least-squares analysis of data with unequal subclass frequencies. USDA Agricultural Research Service, originally published as ARS 20-8, 1960. Reprinted with corrections of minor errors as ARS $\mathrm{H}-4,1975$.

Hill, F. 1966. The solubility of intramuscular collagen in meat animals of various ages. J. Food Sci. 31:161.

Judge, M. D., E. D. Aberle, H. R. Cross and B. D. Schanbacher. 1984. Thermal shrinkage temperature of 
intramuscular collagen of bulls and steers. J. Anim. Sci. 59:706.

McClain, P. E. 1969. Isolation of intramuscular connective tissue. Nature 221:181.

McClain, P. E. and E. R. Wiley. 1972. Differential scanning calorimeter studies of the thermal transitions of collagen. J. Biol. Chem. 247:692.

Meyer, H.H.D. and M. Rapp. 1985. Estrogen receptor in bovine skeletal muscle. J. Anim. Sci. 60:294.

Miller, L. F., M. D. Judge, M. A. Diekman, R. E. Hudgens and $E$. D. Aberle. 1989. Relationships among intramuscular collagen, serum hydroxyproline and serum testosterone in growing rams and wethers. J. Anim. Sci. 67:698.

Schanbacher, B. D. 1980a. Testosterone regulation of luteinizing hormone and follicle stimulating hormone secretion in young male lambs. J. Anim. Sci. 51:679.

Schanbacher, B. D. 1980b. Dose-dependent inhibition of spermatogenesis in mature rams with exogenous testosterone. Int. J. Androl. 3:563.

Schanbacher, B. D., M. P. Johnson and D. J. Tindall. 1987. Androgenic regulation of luteinizing hormone secretion: Relationship to androgen binding in sheep pituitary. Biol. Reprod. 36:340. 